УДК 349.4

DOI $10.21661 / r-530439$

\title{
3.Б. Цолоев
}

\section{ЭФФЕКТИВНОСТЬ ГОСУДАРСТВЕННОГО РЕГУЛИРОВАНИЯ ВОПРОСОВ НЕДРОПОЛЬЗОВАНИЯ НА ПРИМЕРЕ ДЕПАРТАМЕНТА НЕДРОПОЛЬЗОВАНИЯ И ПРИРОДНЫХ РЕСУРСОВ}

Аннотация: в рамках статьи рассмотрены основные аспекты регулирования государственного управления недропользованием на примере Ханть-Мансийского автономного округа - Югры. Актуальность статьи определяется тем, что от качественного и эффективного государственного (правового) регулирования недропользованием зависит дальнейиее развитие рассматриваемого субъекта РФ. Значимость вопроса государственного регулирования деятельности субъектов недропользования обосновывается тем, что экономика России имеет ярко выраженную сырьевую направленность. В связи с чем в статье проведен анализ деятельности Департамента недропользования и природных ресурсов Ханты-мансийского автономного округа - Югры, обеспечивающчий наличие эффрективного механизма недропользования в регионе.

Ключевые слова: нефть, недропользование, природопользование, природные ресурсы, государственное регулирование, лищензирование, правовой режим недропользования, дорожные картыл.

\section{Z.B. Tsoloev}

\section{EFFICIENCY OF STATE REGULATION OF SUBSOIL USE ISSUES (ON THE EXAMPLE OF THE DEPARTMENT OF MINERAL USE AND NATURAL RESOURCES)}

Abstract: in this article, the main issues of legal regulation of state administration of subsoil use in the Khanty-Mansi Autonomous Okrug - Yugra are considered. The relevance of the article is determined by the fact that the Okrug's further development depends on the effective state (legal) regulation of subsoil use. The importance of the issue of state regulation of the activities of subsoil use entities is due to the fact that the 
Russian economy has a pronounced raw material orientation. In this connection, the article analyzes the activities of the Department of Subsoil Use and Natural Resources of the Khanty-Mansi Autonomous Okrug - Yugra, which ensures the existence of an effective mechanism for subsoil use management in the region.

Keywords: oil, subsoil use, nature management, natural resources, state regulation, licensing, legal regime of subsoil use, subsoil use legislation.

Ни для кого не является секретом тот факт, что Российская Федерация является лидером по добыче основных видов полезных ископаемых. На территории Российской Федерации расположено порядка 20 тыс. месторождений различных полезных ископаемых [15, с. 84]. В их число входят выявленные и разведанные в природных недрах страны: нефть, газ, уголь, черные руды, благородные виды металлов, драгоценных камней и т. д.

К наиболее крупным ресурсным регионам России, на долю которых приходится большая часть недр, относятся в первую очередь регионы Севера, Западной Сибири, Арктический шельф. В число таких регионов входит и Ханты-Мансийский автономный округ - Югра (ХМАО-Югра). ХМАО-Югра располагает огромным природно-ресурсным потенциалом, является ключевым нефтегазоносным регионом России и одним из крупнейших нефтедобывающих регионов мира. В настоящее время на ХМАО-Югру приходится более 50\% добычи нефти в стране (1-е место), а по добыче газа регион после Ямало-Ненецкого автономного округа занимает второе место [16, с. 71].

Однако ХМАО-Югра отличается не только своими богатыми месторождениями полезных ископаемых, но и своими механизмами государственного регулирования вопросов недропользования. В качестве доказательства можно привести тот факт, что процесс предоставления участков недр в пользование нефтяным компаниям на основе конкурса ХМАО-Югра начал внедрять и практиковать одним из первых регионов РФ. Кроме того, необходимо подчеркнуть, что законодательная база ХМАО-Югры, которая направлена на регулирование отношений в сфере недропользования, представляет собой более развитую по 
сравнению с другими субъектами РФ. Фундаментом законодательной базы ХМАО-Югры являются несколько основных законов, прежде всего направленных на регламентацию общих положений и решение общих вопросов недропользования, проблем освоения недр и добычи природных ресурсов и, наконец, порядок пользования недрами на условиях соглашения о разделе продукции (СРП). Помимо основных законов на территории ХМАО-Югры действует более двадцати нормативно-правовых актов, направленных на реализацию механизмов и инструментов законодательного регулирования недропользования, которые были приняты непосредственно администрацией округа [13, с. 53]. В этих документах отражаются экономические, социальные, природные и другие характерные особенности связанные с процессами использования недр.

Принимая во внимание тот факт, что в целом для экономики России и рассматриваемого субъекта в частности характерной чертой является сырьевая направленность, а минерально-сырьевой сектор является одним из первостепенно значимых секторов в экономике ХМАО-Югры, формирует большую часть валового регионального продукта, способствует притоку инвестиций в регион, определяет бюджетную ситуацию, инфраструктурное развитие, структуру экспорта и пр., государственное регулирование вопросов недропользования должно отвечать современным реалиям, быть эффективным и способствовать рациональному использованию недр.

Государственное регулирование недропользования представляет собой решение соответствующими органами федеральной исполнительной власти и органами субъектов Российской Федерации, в рамках вверенных им полномочий и компетенций, целого ряда вопросов касаемо системы недропользования [15, с. 84]. К таким вопросам можно отнести непосредственно реализацию самого механизма недропользования, охрану недр, охрану окружающей среды.

Государственное регулирование отношений в сфере недропользования реализуется за счет управления, лицензирования, учета и контроля (надзора) недр [9, с. 66]. 
Федеральным Законом РФ от 21.02.1992 №2395-1 «О недрах» определен целый ряд задач, стоящих перед государственным регулированием вопросов недропользования. Например, определение объемов добычи полезных ископаемых как на текущие периоды, так и на перспективу, установление квот на поставку добываемого минерального сырья, введение необходимых платежей, связанных с пользованием недрами, регулирование цен на отдельные виды природных ресурсов и т. д. [2].

Из всей совокупности задач, поставленных перед государственным регулированием вопросов недропользования, можно выделить первостепенную задачу, которая заключается в обеспечение воспроизводства минерально-сырьевой базы, ее рационального использования и охраны недр в интересах всего народа, последующих поколений и будущего страны в целом [10, с. 96].

Решением совокупности задач, которые связаны с недропользованием занимаются федеральные органы власти и региональные органы власти РФ, которые при помощи уполномоченных институтов осуществляют реализацию предоставления недр в пользование заинтересованным лицам, надзор, учет, контроль и охрану над использованием недр.

На территории ХМАО-Югры в качестве такого специального института выступает Департамент недропользования и природных ресурсов Ханты-Мансийского автономного округа - Югры (Депнедра и природных ресурсов Югры). Именно на данный департамент возложена задача реализации государственной политики в целом и в частности государственного регулирования вопросов недропользования.

Департамент недропользования и природных ресурсов ХМАО-Югры был сформирован путем преобразования, действовавшего ранее Департамента по нефти, газу и минеральным ресурсам ХМАО-Югры. В соответствие с Постановлением губернатора Ханты-Мансийского автономного округа - Югры о Департаменте недропользования и природных ресурсов Ханты-Мансийского автономного округа - Югры №157 от 22.12.2016. Департамент недропользования и природных ресурсов ХМАО-Югры представляет собой «исполнительный орган 
государственной власти Ханты-Мансийского автономного округа - Югры, который осуществляет функции по реализации единой государственной политики и нормативному правовому регулированию, управлению государственным имуществом, оказанию государственных услуг в сфере геологического изучения, использования и охраны недр, модернизации топливно-энергетического комплекса и рационального использования углеводородного сырья, лесных и водных отношений, использования, воспроизводства, охраны объектов животного мира и среды их обитания, организации и функционирования особо охраняемых природных территорий регионального значения» [7].

Осуществляя свою деятельность по вопросам недропользования, департамент руководствуется законами и нормативными правовыми актами Российской Федерации и Ханты-Мансийского автономного округа, распорядительными актами органов исполнительной власти Российской Федерации и Ханты-Мансийского автономного округа, изданными в пределах их компетенции, а также внутренними документам департамента. В качестве примера таких документов можно привести следующее: Приложение 1 к постановлению Губернатора Ханты-Мансийского автономного округа - Югры от 22 декабря 2016 года №157, в котором перечислены полномочия департамента в рассматриваемой сфере деятельности. В соответствие с данным приложением департамент наделен полномочиями оформлять и выдавать лицензии на пользование недрами, выдавать иные разрешительные документы, осуществлять различного рода меры [7]. Здесь необходимо отметить, что в декабре 2019 года департамент заявил о досрочном прекращении с 20 апреля 2020 года права пользования участком недр местного значения «Разработка карьера песка №3 на Сысконсыньинском лицензионном участке» (лицензия ХМН 01683 ОЭ), предоставленного АО «НОВАТЭК-Пур» для разведки и добычи общераспространенных полезных ископаемых (песок) [17].

В целом, можно говорить, что всю совокупность задач, стоящих перед департаментом, можно свести к ключевым задачам государственного 
регулирования недропользования, а это, как уже было отмечено ранее, управление, лицензирование, учет, надзор и контроль недр.

Говоря о эффективности государственного регулирования вопросов недропользования, осуществляемого департаментом, необходимо отметить, что департамент принимает активное участие в разработке и реализации государственных программ геологического изучения, развития и освоения минерально-сырьевой базы автономного округа, в распоряжении государственным фондом недр в установленном порядке. Разрабатывает и осуществляет непосредственно территориальные программы развития и использования минерально-сырьевой базы. Так, например, из бюджета ХМАО-Югры на реализацию государственной программы «Развитие и использование минерально-сырьевой базы Ханты-Мансийского автономного округа - Югры на 2014-2020 годы» было выделено 518,72 млн. руб., общая сумма внебюджетных источников составила 3 421,40 млн. руб. [17]. Среди других программ, реализуемых на территории ХМАО-Югры, можно выделить такие программы, как «Воспроизводство и использование природных ресурсов», «Региональный проект «Сохранение лесов», «Развитие лесного хозяйства и лесопромышленного комплекса Ханты-Мансийского автономного округа - Югры с 2016 по 2020 годы» и ряд других программ [17].

Однако, несмотря на активную работу Департамента по недропользованию и природным ресурсам ХМАО-Югра имеет место быть и комплекс проблем в данной сфере. В первую очередь речь идет о необходимости совершенствования законодательства в части уточнения содержания и механизмов выдачи лицензий на пользование недрами. Как отмечают специалисты, лицензия должна содержать четко зафиксированные сроки исполнения отдельных обязательств недропользователя - от срока начала работ по изучению и разведке месторождений до момента фактического ввода в эксплуатацию того или иного участка недр [14, с. 110].

Для ХМАО-Югры, учитывая тот факт, что регион является лидером по добычи нефти, газа и ряда других природных ресурсов, такого рода вопросы имеют 
большое практическое и востребованное решение. Эффективная система лицензирования недр является безусловным фактором развития минерально-сырьевой отрасли ХМАО-Югры, и в первую очередь нефтедобывающей отрасли. Регулированием вопросов прочтения лицензий и их содержания имеет не только колоссальное значение, но и выступает в качестве важнейшего элемента для построения конструктивных взаимоотношений с недропользователями. Обосновать это можно тем, что по ХМАО-Югре лицензионные объемы по сейсморазведочным работам на поисковых блоках выполняются только крупными нефтяными компаниями [14, с. 111].

Говоря о лицензировании, хотелось бы обратиться к некоторым статистическим данным по ХМАО-Югре. Так, в 2019 году правительство ХМАО-Югры направило в Федеральное агентство по недропользованию РФ (Роснедра) предложения по формированию программы лицензирования на 2019 год 16 участкам, на 2020 год по 7 участкам (речь идет о нефти) [17]. Безусловно, вопросы лицензирования затрагивают не только нефтяную отрасль. Лицензии на пользование недрами выдаются и на другие природные ресурсы - водные, лесные. На начало октября 2019 года Департаментом по недропользованию и природным ресурсам ХМАО-Югра было предоставлено 121 лицензия на пользования недрами с целью добычи подземных вод, в том числе 115 лицензий на пользование участками недр местного значения и 6 лицензий на пользование недр с объемом добычи более 500 м³/сутки [17]. Однако, по заявкам самих недропользователей 53 лицензии на пользование недрами были досрочно прекращены [17].

В качестве еще одной проблемы государственного регулирования вопросов недропользования в ХМАО-Югре выступают коллизии интересов участников процесса пользования недрами, в первую очередь непосредственно государства и недропользователей. Весьма часто на практике интересы этих групп являются крайне противоположными, а иногда и вовсе взаимоисключающими. Решение данной проблемы должно заключаться не в том, чтобы установить единые для всех «правильные» или «неправильные» интересы на уровне государственного законодательства. Для урегулирования несовпадения интересов участников, в 
той или иной степени принимающих участие в недропользовании, более действенным будет поиск баланса, равновесия, условия которых являлись бы удовлетворительными и приемлемыми для всех заинтересованных сторон.

Таким образом, можно сделать вывод о том, что, несмотря на существующие высокие объемы добычи полезных ископаемых наличие на территории ХМАО-Югры их больших запасов, в целях обеспечения будущего стабильного развития минерально-сырьевой отрасли необходимо со стороны государства принятия таких мер, которые поспособствовали созданию условий и заинтересованности со стороны нефтегазодобывающих и других компаний для ввода в разработку существенного количества запасов и ресурсов.

Резюмируя сказанное вышесказанное, можно сделать некоторые выводы. Во-первых, Ханты-Мансийский автономный округ - Югра представляет собой стратегический для страны регион, который выполняет значительную роль в обеспечении энергетической безопасности Российской Федерации. Обосновано это тем, что регион является одним из лидеров по объему добычи нефти, природного и попутного газа, и генерации электроэнергии.

Органами государственной власти Ханты-Мансийского автономного округа - Югры осуществляется государственное регулирование вопросов недропользования по средствам реализации полномочий, которые установлены Конституцией Российской Федерации и Законом Российской Федерации «О недрах».

Деятельность Департамента по недропользованию и природным ресурсам Ханты-Мансийского автономного округа - Югры направлена на решение задач по проведению государственной политики в сфере изучения, воспроизводства, использования и охраны ресурсов недр и водных объектов в пределах компетенции и предметов ведения Ханты-Мансийского автономного округа- Югры. Также департамент принимает участие в разработке и реализации различных государственных программ в сфере недропользования, в распоряжении государственным фондом недр в установленном порядке, в разработке и осуществлении государственной энергетической политики на территории ХМАО-Югры. 
В настоящее время деятельность департамента направлена на сохранение и стабилизацию уровня добычи нефти. Для этого в округе получили популярность так называемые «дорожные карты». Реализация дорожных карт позволяет существенно сократить сроки административных и согласовательных процедур и позволяет добывающим компаниям в более сжатые сроки вовлечь в разработку запасы новых месторождений. На сегодняшний день на территории Ханты-Мансийского автономного округа - Югры действуют 5 таких «дорожных карт» по 11 лицензионным участкам. При этом необходимо отметить, что опыт использования такого рода дорожных карт является весьма положительным, в связи с чем можно говорить о весьма эффективной работе Департамента по недропользованию и природным ресурсам Ханты-Мансийского автономного округа - Югры.

\section{Список литературы}

1. Конституция РФ [Электронный ресурс]. - Режим доступа: http://www.consultant.ru/document/cons_doc_LAW_28399/

2. Федеральный закон РФ от 21.02.1992 №2395-1 «О недрах» [Электронный pecypc]. - Режим доступа: http://www.consultant.ru/document/cons_doc_LAW_ $343 /$

3. Федеральный закон «О лицензировании отдельных видов деятельности» от 04.05.2011 №99-Ф3 [Электронный ресурс]. - Режим доступа: http://www.consultant.ru/document/cons_doc_LAW_113658/

4. Закон Ханты-Мансийского автономного округа - Югры «О недропользовании» от 18.04.1996 г. №15-оз [Электронный ресурс]. - Режим доступа: http://docs.cntd.ru/document/429028657

5. Закон Ханты-Мансийского автономного округа - Югры от 31.12.2004 г. №94-оз «О внесении изменений и дополнений в Закон Ханты-Мансийского автономного округа «О недропользовании» [Электронный ресурс]. Режим доступа: http://docs.cntd.ru/document/991016305

6. Положение об управлении по недропользованию по Ханты-Мансийскому автономному округу - Югре (утв. Приказом Роснедр от 19.01.2007 №57) 
[Электронный ресурс]. - Режим доступа: http://www.consultant.ru/document/ cons_doc_LAW_266679/

7. Постановление губернатора Ханты-Мансийского автономного округа Югре о департаменте недропользования и природных ресурсов Ханты-Мансийского автономного округа - Югры №157 от 22.12.2016. [Электронный ресурс]. Режим доступа: https://depprirod.admhmao.ru/dokumenty/hmao/781781/

8. Быстриченко М.Г. Основные направления развития недропользования в Ханты-мансийском автономномном округе - Югре // Экономические и социальные факторы развития народного хозяйства: материалы IV Региональной научно-практической конференции аспирантов и магистрантов. - 2016. C. $177-183$.

9. Василевская Д.В. Право недропользования: учебник. - М.: Зерцало, 2016. -283 c.

10. Карчевский А.О. Анализ эффективности государственного регулирования отношений в сфере пользования недрами // Economics. - 2018. - №6. C. 94-99.

11. Кузьменков С.Г. В Югре создается полигон «Баженовский» // Недропользование XXI век. - 2014. - №5 (49). - С. 9-11.

12. Новоселов А.Л. Экономика, организация и управление в области недропользования: учебник и практикум / А.Л. Новоселов, О.Е. Медведева, И.Ю. Новоселова. - М.: Юрайт, 2015.

13. Ратникова Н.Е. Правовые основы недропользования на территории Ханты-мансийского автономного округа Российской Федерации // World Science: Problems and Innovations: сборник статей победителей XI Международной научно-практической конференции: в 2-х ч. - 2017. - С. 52-55

14. Рыльчикова С.Л. Пользование недрами Ханты-мансийского автономного округа - Югры / С.Л. Рыльчикова, М.В. Тихонова, Н.Л. Таркова [и др.] // Недропользование XXI век. - 2018. - №4 (74). - С. 108-125. 
15. Семенова А.А. Правовое регулирование разработки и добычи полезных ископаемых. Федеральные и региональные аспекты (Тюменская область, Красноярский край) // Молодой ученый. - 2018. - №13. - С. 84-91

16. Толстолыткин И.П. Этапы освоения нефтяных месторождений ХМАОЮгры: 1964-2017 гг. // Недропользование XXI век. - 2018. - №4 (74). - С. 70-75.

17. Департамент недропользования и природных ресурсов Ханты-Мансийского автономного округа - Югры [Электронный ресурс]. - Режим доступа: https://depprirod.admhmao.ru

\section{References}

1. Konstitutsiia RF. Retrieved from http://www.consultant.ru/document/cons_doc_LAW_28399/

2. Federal'nyi zakon RF ot 21.02.1992 2395-1 "O nedrakh". Retrieved from http://www.consultant.ru/document/cons_doc_LAW_343/

3. Federal'nyi zakon "O litsenzirovanii otdel'nykh vidov deiatel'nosti" ot 04.05.2011 99-FZ. Retrieved from http://www.consultant.ru/document/cons_doc_LAW_113658/

4. Zakon Khanty-Mansiiskogo avtonomnogo okruga. Retrieved from http://docs.cntd.ru/document/429028657

5. Zakon Khanty-Mansiiskogo avtonomnogo okruga. Retrieved from http://docs.cntd.ru/document/991016305

6. Polozhenie ob upravlenii po nedropol'zovaniiu po Khanty-Mansiiskomu avtonomnomu okrugu. Retrieved from http://www.consultant.ru/document/cons_doc_LAW_266679/

7. Postanovlenie gubernatora Khanty-Mansiiskogo avtonomnogo okruga. Retrieved from https://depprirod.admhmao.ru/dokumenty/hmao/781781/

8. Bystrichenko, M. G. (2016). Osnovnye napravleniia razvitiia nedropol'zovaniia v Khanty-mansiiskom avtonomnomnom okruge. Ekonomicheskie i sotsial'nye faktory razvitiia narodnogo khoziaistva, S. 177.

9. Vasilevskaia, D. V. (2016). Pravo nedropol'zovaniia., 283. M.: Zertsalo. 
10. Karchevskii, A. O. (2018). Analiz effektivnosti gosudarstvennogo regulirovaniia otnoshenii v sfere pol'zovaniia nedrami. Economics, 6, 94-99.

11. Kuz'menkov, S. G. (2014). V Iugre sozdaetsia poligon "Bazhenovskii". Nedropol'zovanie XXI vek, 5 (49), 9-11.

12. Novoselov, A. L., Medvedeva, O. E., \& Novoselova, I. Iu. (2015). Ekonomika, organizatsiia i upravlenie v oblasti nedropol'zovaniia: uchebnik i praktikum. M.: Iurait.

13. Ratnikova, N. E. (2017). Pravovye osnovy nedropol'zovaniia na territorii Khanty-mansiiskogo avtonomnogo okruga Rossiiskoi Federatsii. World Science: Problems and Innovations: sbornik statei pobeditelei XI Mezhdunarodnoi nauchnoprakticheskoi konferentsii, S. 52.

14. Ryl'chikova, S. L., Tikhonova, M. V., \& Tarkova, N. L. (2018). Pol'zovanie nedrami Khanty-mansiiskogo avtonomnogo okruga. Nedropol'zovanie XXI vek, 4 (74), 108-125.

15. Semenova, A. A. (2018). Pravovoe regulirovanie razrabotki i dobychi poleznykh iskopaemykh. Federal'nye i regional'nye aspekty (Tiumenskaia oblast', Krasnoiarskii krai). Molodoi uchenyi, 13, 84-91.

16. Tolstolytkin, I. P. (2018). Etapy osvoeniia neftianykh mestorozhdenii KhMAO-Iugry: 1964-2017 gg. Nedropol'zovanie XXI vek, 4 (74), 70-75.

17. Departament nedropol'zovaniia i prirodnykh resursov Khanty-Mansiiskogo avtonomnogo okruga. Retrieved from https://depprirod.admhmao.ru

Цолоев Заурбек Багаундинович - студент, Институт государственной службы и управления ФГБОУ ВО «Российская академия народного хозяйства и государственной службы при Президенте РФ», Москва, Россия.

Tsoloev Zaurbek Bagaundinovich - student, Insitute of Public Administration and Civil Service, FSBEI of HE "Russian Presidential Academy of National Economy and Public Administration under the President of the Russian Federation", Moscow, Russia. 